\title{
Символика валунной кладки в архитектуре Восточной Пруссии (Калинин- градская область) XIII - первой половины XX века ${ }^{1}$
}

\author{
И.В.Белинцева, НИИТИАГ, Москва
}

Территория на берегу Балтийского моря (частично относящаяся к Калининградской области РФ), отвоёванная рыцарями Тевтонского ордена у языческих племен пруссов, изначально воспринималась символически - как замена утраченной Святой земли с центром в Иерусалиме. Кёнигсберг (совр. Калининград) в виде Иерусалима представлен в эпитафии Г. Нимпча (худ. Г. Кенигсвизер, после 1556 года. Музей Вармии и Мазур. Ольштын, Польша). Вблизи столицы когда-то стоял замок Иерусалим, куда совершали паломничество рыцари со всей Европы, чтобы выполнить обет и совершить крестовый поход в утраченный земной Иерусалим. В эпоху Средневековья в северной части Восточной Пруссии из полевых камней (обычно в сочетании с кирпичом) возводили первые храмы и укрепления Тевтонского ордена. Использование валунов в храмовом и крепостном строительстве связывалась с идеей Небесного идеального града, сложенного из «живых камней». К числу ранних сооружений из полевого камня относится храм в бывшем Юдиттене (совр. Менделеево вблизи Калининграда) и другие культовые здания. Здания в «валунном стиле» вновь появились на этой территории в середине XIX - первой половине XX века, что связано с движением национального романтизма и обращением к древним традициям европейской архитектуры. К малоизученным объектам конца XIX - первой половины XX века относятся храм в Пальмникене (совр. Янтарный, 1887-1892), храм в Аугстагиррене (совр. Сосновка, арх. Ф.Ларс, 1923), башни Бисмарка (нач. XX в.), так называемый «партайбург» в Рагните (совр. Неман, до 1933) и другие сооружения. Символика образного решения сооружений из полевого камня остаётся до конца невыясненной.

Ключевые слова: Восточная Пруссия, XIII - первая половина XX века, Калининградская область, Тевтонский орден, христианская символика, валунный камень, строительство, крепости, храмы, башни, национальный романтизм.

Symbols of Boulder Masonry in the Architecture of East Prussia (Kaliningrad Region) XIII - First Half of XX Century I.W.Belintseva, NIITIAG, Moscow

The territory on the Baltic sea (partly related to the Kaliningrad region of the Russian Federation), conquered by

\footnotetext{
${ }^{1}$ Исследование выполнено за счёт средств Государственной программы Российской Федерации «Развитие науки и технологий» на 2013-2020 годы» в рамках Плана фундаментальных научных исследований Минстроя России и РАACH, тема 1.2.23
}

the Teutonic Knights from pagan tribes of Prussians, initially perceived symbolically as a replacement for alost Holyland with its center in Jerusalem. Konigsberg (modern Kaliningrad) in the view of Jerusalem is presented in the epitaph $\mathrm{H}$. Nimptsch (hood. G. Koenigswieser, after 1556. Museum of Warmia and Mazury. Olsztyn, Poland). Near the capital once stood the castle of Jerusalem, where knights from all over Europe made a pilgrimage to fulfill a vow and make a crusade to the lost earthly Jerusalem. In the Middle Ages in the Northern part of East Prussia, the first temples and fortifications of the Teutonic order were built of fieldstones (usually in combination with brick). The use of boulders in temple and fortress construction was associated with the idea of a Heavenly ideal city, composed of "living stones". Among the early structures of fieldstone are the temple in the former Judytten (modern Mendeleevo near Kaliningrad) and other religious buildings. Buildings in the "boulder style" reappeared in this area in the mid-XIX - first half of the XX century, which is associated with the movement of national romanticism and appeal to the ancient traditions of European architecture. The little-studied objects of the late XIX - first half of the XX century include the temple in Palmnicken (modern Jantarnyj, 1887-1892), the temple in Augustagirren (modern Sosnovka, arch. F. Lahrs, 1923), the towers of Bismarck (early XX century), the so-called "partayburg" in Ragnit (modern Neman, until 1933) and other structures. The symbolism of the figurative solution of structures made of fieldstone remains unclear.

Keywords: East Prussia, Kaliningrad region, Teutonic Order, boulder stone, construction, fortresses, temples, towers, Christian symbols, architectural samples, 19 - first half of the 20th century, national romanticism.

Современная Калининградская область РФ занимает северо-восточную часть бывшей германской провинции Восточная Пруссия и представляет собой специфический регион с историческими архитектурными памятниками, остающимися неизученными до настоящего времени. Новым поселенцам долгие десятилетия после окончания Второй мировой войны не разрешалось знать и размышлять о былой жизни края, прежние жители провинции, выселенные в Германию, старались забыть довоенное прошлое. В результате образовалась удивительная лакуна в научных исследованиях местной архитектуры, которая в настоящее время активно заполняется. 
Территория южного побережья Балтики (с 1893 года - немецкие провинции Восточная и Западная Пруссия) в (редние века находилась под властью государства Тевтонского ордена, созданного в начале XIII века при поддержке римского папы и германского императора Фридриха II - представителей двух универсальных властей средневековья². Рыцарское государство занимало обширные земли завоёванных прусских и славянских племён, простираясь от Мемеля (совр. Клайпеда, Литва) до западных берегов Вислы, от побережья Балтики до Торна (совр. Торунь, Польша), включая Мазуры ${ }^{3}$.

Орден был чётко организованной иерархической структурой, твёрдо закреплённой уставом. Такой же ясностью и последовательностью отличалась его строительная деятельность, основанная на тогдашних представлениях о «порядке» (ордо). «В связи с идеей ордо вполне логичным выглядит высказывание орденского хрониста Петра из Дуйсбурга в “Хронике земли прусской": “Кажется, что это рыцарство, по образу неба и земли созданное, является единственным и главнейшим, которое вместо Христа будет страдать при поругании креста Его и посвятит себя делу отвоевания Святой земли обетованной от гнета языческого"» [Цит. по: 1, с. 46] Захватывая в кровавой борьбе территорию у язычниковпруссов, рыцари способствовали её включению в зону воздействия христианского мира, занимались организаторской, хозяйственной и строительной деятельностью, возводили десятки мощных замков и закладывали города и деревни. В многочисленных ритуалах орденских братьев символически соблюдались предписания Нового Завета.

Территория пруссов изначально воспринималась европейцами символически - как замена утраченной Святой земли с центром в Иерусалиме. Колонизаторская деятельность на берегах Балтики была пронизана одновременно рационализмом и отличалась художественным своеобразием. Для рыцарей Тевтонского ордена в качестве архитектурно-градостроительного идеала выступал утраченный христианами, но ещё свежий в памяти тогдашних рыцарей священный город Иерусалим и его чтимый небесный прообраз. Средневековый австрийский хронист Оттокар фон Хорнек описывал в 1310 году, как тогдашний магистр Ордена Конрад фон Фейхтванген, отдав приказание кораблям отплывать из Азии, обещал, что за поражения, понесённые на Востоке, будет отомщено неверным в Пруссах и Инфлантах [2, s. 107].

\footnotetext{
2 После политического деления страны в результате Торуньского мира (1466) и превращения остатка Орденского государства в светское герцогство сохранилось общее обозначение балтийских земель - Пруссия, с выделением Княжеской (герцогской) Пруссии и Королевской Пруссии. В то время как Западная (Королевская) Пруссия перешла во владения польской короны, последний Великий магистр Ордена в Восточной Пруссии Альбрехт фон Бранденбург-Ансбах Гогенцоллерн в 1525 году превратил остатки Орденского государства в евангелическое герцогство - Княжескую Пруссию, признав себя вассалом Польши.

${ }^{3}$ История государства Тевтонского Ордена охватывает период с 1230 по 1525 год, его расцвет приходится на 1400-е годы.
}

Планировочные правила Средневековья были пронизаны видением Святого города Иерусалима - земного и Небесного, которые влияли на архитектурное формообразование. Как известно, на протяжении нескольких столетий в разных странах и по разным поводам предпринимались попытки воспроизвести в реальном зодчестве образы «дольнего» и «горнего» Иерусалима, его отдельных сооружений или их частей. Понятие Нового Иерусалима переносилось в христианской интерпретации на города, башни, храмовые постройки, всю землю, космос.

Представляется вероятным, что крестоносцы при колонизации завоёванных земель на северо-востоке Европы, закладывая новые поселения, обратились именно к образу утраченного, но не потерявшего святости города. Следуя Апокалипсису, одновременно с упадком былого Иерусалима возникают условия для создания Нового Иерусалима (0ткр. 3:12). Одной из вариаций темы возобновления Иерусалима на земле были орденские города и замки Тевтонского ордена на Балтийском побережье. Обращает на себя внимание характерный облик рыцарских укреплений - в форме квадрата, обнесённого стеной, иногда с высокими башнями по углам. Согласно Апокалипсису, Небесный Иерусалим «имеет большую и высокую стену... Город расположен четвероугольником и длина его такая же, как широта» (0ткр. 21:12, 16). Следует учитывать, что в тексте, рисующем «sankta civitas», или «Новый Иерусалим», появившийся в Апокалипсисе от Иоанна, который датируется I-II веками нашей эры, вполне могла сказаться преемственность с традициями языческой античности и её устойчивыми представлениями о регулярном городе, подобном римскому каструму.

В музее Вармии и Мазур в Ольштыне (Польша) хранится эпитафия жителя Кёнигсберга Ганса Нимпча (1476-1556), находившаяся когда-то в северном нефе кёнигсбергского собора. Простая композиция включала живописное изображение распятия в обрамлении полуколонок, несущих архитрав, над которым в треугольнике фронтона расположено изображение Бога Отца. Наибольший интерес в этом памятнике вызывает представленный на заднем плане в виде земного Иерусалима город Кёнигсберг с узнаваемыми башнями и шпилями церквей. Картина была создана придворным художником герцога Альбрехта, самым значительным живописцем Кенигсберга XVI века - Генрихом Кёнигсвизером (ок. 1530-1583), который прошёл выучку у известного мастера Лукаса Кранаха, чрезвычайно его хвалившего в письмах к бывшему хохмайстеру Ордена, позднее светскому властителю восточно-прусских земель.

Недалеко от Кёнигсберга Прусского существовал замок, называемый Иерусалим (не сохр.), давший впоследствии название городскому району. Русский путешественник начала XIX века писал о нём: «Иерусалим, удалённый от Кёнигсберга на расстояние трёх четвертей часа, есть, бесспорно, самое приятное место на подобном расстоянии от города. Из окон 
замка, который превращён в гостиницу, открывается лучший вид на Кёнигсберг, который раскрывается амфитеатром... Прямо под окнами дворца течёт рукав Преголи... Название этого места имеет особенное происхождение. Немецкие рыцари при их приёме в Орден должны были совершить крестовый поход (паломничество) в Иерусалим, который был начальной целью Ордена. После утраты священных могил они не могли выполнить свой обет, но стремились, по крайней мере, держать данное слово. Поэтому они возвели в этом месте замок, назвали его Иерусалим, и успокаивали свою совесть тем, что устраивали сюда паломничества и забавлялись здесь турнирами» [3, s. 11].

B XIV-XV веках походы в Пруссию были чрезвычайно популярны среди рыцарей Европы, в том числе и крестоносцев, не принадлежавших к членам Тевтонского ордена. Участие в военных действиях против язычников на южных берегах Балтики считалось особой заслугой и привилегией и было сравнимо по значимости с паломничеством в Рим, Иерусалим, Сантьяго да Кампостела. В Кёнигсберге Прусском в ожидании выступления в поход воины-аристократы со всей Европы - из Англии, Шотландии, Северной и Южной Италии, Арагона, Португалии, Германии - проводили время в пирах, охотах, турнирах. Великий магистр устраивал специальные обеды, на которых избиралось 12 почётных гостей из разных королевств. Внутренний смысл и символика здешних рыцарских ритуалов остаётся до сих пор предметом споров среди исследователей [4, s. 30].

При освоении прусских земель, которые заменили немецкому Ордену священную землю Палестины, он упрочивал свое господство возведением замков и храмов - первоначально из полевых неотёсанных валунов или полуобработанных камней (крупных, обычно грубо околотых, разного размера, часто в сочетании с кирпичом). Широкое использование валунных блоков, в изобилии встречавшихся на полях Восточной Пруссии, особенно в Самбии (совр. Калининградский полуостров), вызвано было не только

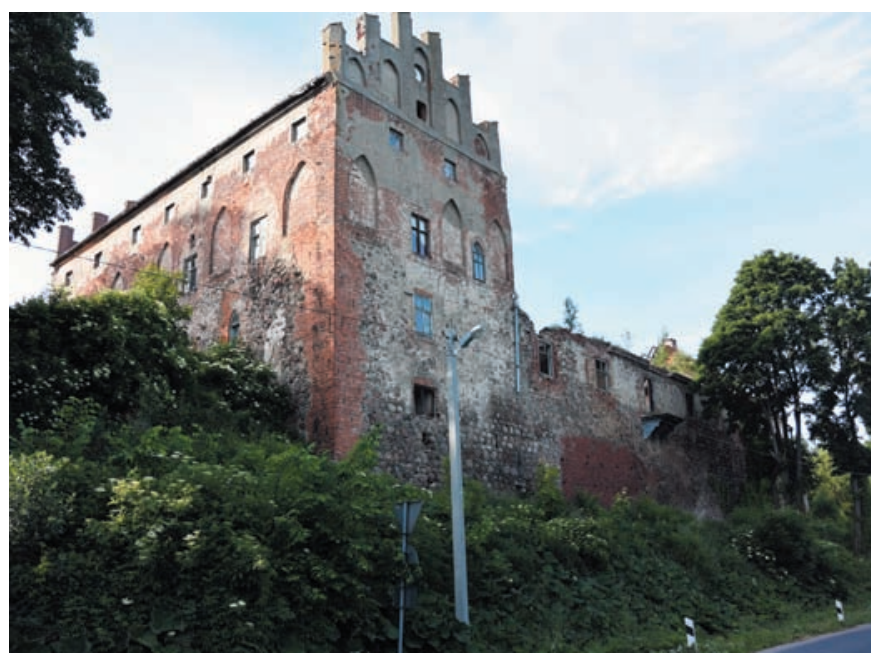

Рис. 1. Замок в Маёвке (бывщий Георгенсбург). 1351 год. Фото автора. 2017 год необходимостью быстрого возведения укреплённых объектов, доступностью строительного материала, буквально лежащего под ногами, но утверждением духовного авторитета, опиравшегося на распространённую христианскую символику. Хорошо известно, что текст Библии пронизан архитектурными метафорами каменного строительства. В литургии, в мессе, во время освящения церквей повторялась мысль о Небесном идеальном граде, построенном из «живых камней». Религиозная литература Средневековья сопоставляла церковь как организацию и социальный институт, и Небесный город, отличавшийся стройной упорядоченностью, что временами доходило до их взаимного отождествления. Идея взыскуемого Небесного града со временем твёрдо и прочно укоренилась в христианской культуре. Две основные мысли лежали в основе средневековых представлений: учение о том, что Небесный город (он же церковь) - не стоит готовым, но должен быть построен христианами; и о том, что каждый член общества представляет собой «живой камень» и необходимую составляющую Небесного Града. Небесное «идеальное место» в средневековой немецкой литературе непременно связывалось с идеальным городом из библейских текстов [5, s. 84].

Стены из валунов и булыжников редко использовались для жилых помещений, камни обычно служили основанием крепостей и замков, а также применялись при строительстве храмов. Для кладки брали камни-валуны различных цветов: коричневые, красноватые, черные, серые. Стенные поверхности отличались богатством колорита и живописностью. Крупные валуны раскалывались с помощью огня и укладывались в стену относительно ровной поверхностью наружу. Получившиеся щели между крупными камнями заполнялись мелкими обломкам или замазывались известковым раствором. Для придания большей декоративности поверхностям стен в сырой светлый раствор забивали мелкие осколки камней. Нередко углы и края дверных и оконных проёмов в постройках, возведённых из естественного камня, делались из кирпича.

Первые этажи и фундаменты крепостей на завоёванной территории прусских племён первоначально выкладывались исключительно из валунов, что можно наблюдать в частично сохранившихся замках XIV века в бывшем Тапиау (совр. Гвардейск), в бывшем замке самбийских епископов Георгенсбурге (совр. Маёвка вблизи Черняховска) и других (рис. 1). В Рагните замок был полностью возведён на новом месте в 1397-1409 годах под руководством мастера Николауса Фелленштайна из Мариенбурга (совр. Мальборк, Польша). В Тапиау при перестройке первоначального укрепления в 1347-1359 годах построили новый четырёхфлигельный замок в соответствии с общепринятым в Ордене священным библейским образцом (рис. 2). «До высоты главного второго этажа стены были сложены из полевого камня, выше - из обожжённого кирпича. Толщина стен была более трёх метров» [6, с. 465]. 
Замок Инстербург (совр. Черняховск) был заложен в 1336 году магистром Тевтонского ордена Дитрихом фон Альтенбургом на месте прусского городища Унзетрапис, разрушенного в 1256 году. Цитадель расположена на высоком холме у слияния рек Ангерапп, Писса и Инстер, по имени последней он и был назван. Стены первого яруса были выполнены из валунов разного размера. Можно привести множество подобных примеров из истории крепостного строительства Тевтонского ордена.

Возведение католических и евангелических храмов продолжалось в Восточной Пруссии более семисот лет. Начиная с эпохи Средневековья в балтийском регионе создавали сакральные сооружения базиликального типа, обычно с одним, реже - с тремя нефами, и одной высокой западной башней, хотя встречались также двухбашенные решения. Восточные апсиды имели прямоугольный абрис плана, но бывали исключения. К началу Второй мировой войны в северо-восточной части Восточной Пруссии (совр. Калининградская область) существовало более двухсот евангелических и католических церквей.

Среди храмовых сооружений на территории Восточной Пруссии встречались постройки, полностью выложенные из валунов или возведённые с использованием смешанной техники из кирпича и камня. Со временем стали преобладать церкви из красного кирпича. Самые древние храмы были выполнены из неотёсанных полевых камней - валунов. К ним относится храм в честь Святой Девы Марии в Юдиттене (совр. Менделеево). Заново отреставрированная церковь во имя Святого Николая стала первым действующим храмом в истории Калининградской области ${ }^{4}$ (рис. 3).

Церковь в бывшем Юдиттене - не только старейшее место богослужений в Восточной Пруссии: она служила паломническим храмом, где до конца Второй мировой войны хранилось большое количество художественных сокровищ орденского времени [7]. В храме находились фрески конца XIV - начала XV века, раскрытые в 1906-1907 годах, и деревянное изображение Богоматери, считавшееся чудотворным.

В документах церковь Девы Марии была впервые упомянута в 1402 году. Строительство началось предположительно в 1288-1298 годах с возведения хоров. Известный знаток и официальный хранитель древностей Восточной Пруссии XIX века Адольф Бёттихер датировал концом XIII века лишь стены нефа, а пять пролётов оригинально трактованного веерного свода он относил к середине XIV века. На хорах кирхи в начале XIV века был выложен звёздчатый свод [8, s. 61-66]

Здание представляет собой однонефный храм с отдельно стоящей башней-колокольней. Выстроенная из необработанного валунника на растворе, постройка одновременно служила крепостью. Крупноразмерный кирпич использовался для обрамления оконных и дверных проёмов, кладки углов,

${ }^{4}$ В декабре 1986 года в Менделеево (бывш. Юдиттен) состоялось первое православное богослужение на территории Калининградской области. фронтонов, башенок, лестниц. Нижний ярус колокольни также выполнен из валунов, из кирпича в конце XIV века были выложены два верхних этажа. В эпоху Реформации храм стал евангелической приходской церковью. Незадолго до начала Второй мировой войны церковь была отреставрирована, башня покрыта деревянной дранкой, в настоящее время замененной шифером 5 .

Приходская кирха в бывшем Алленау (совр. Поречье) была предположительно заложена Великим магистром Тевтонского

${ }^{5}$ В 1945 году церковь не была повреждена, и вплоть до 1948 года здесь проводились евангелические службы. После окончательного выселения немцев сохранявшееся внутреннее убранство, датируемое XVI-XIX веками, было разграблено и уничтожено, само здание постепенно разрушалось. В 1985 году началась реставрация церкви, закончившаяся в 1987 году освящением храма по православному чину в честь Святителя Николая.

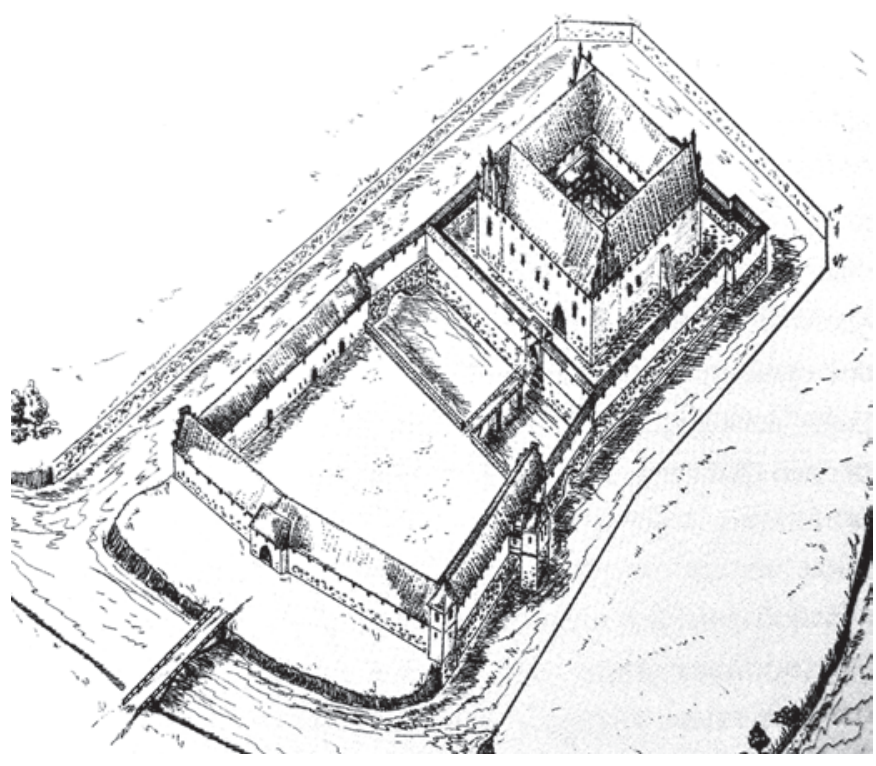

Pис. 2. Замок Tanиау (совр. Гвардейск). Реконструкция А.П. Бахтина. Рисунок А.М. Осипова (источник: Замки и укрепления Немецкого Ордена в северной части Восточной Пруссии. Справочник / Автор-сост. А.П. Бахтин; под ред. В.Ю.Курпакова. - Калининград : Терра Балтика, 2005. - 208 с.)

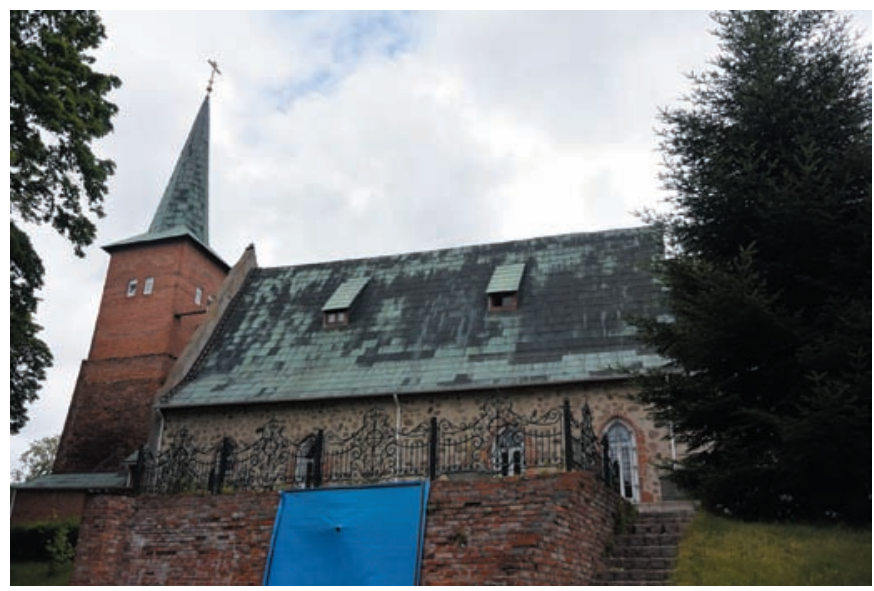

Рис. 3. Храм в Менделеево (бывш. Юдиттен). Фото автора. 2017200 
ордена Ульрихом фон Юнгингеном (1360-1410). Она представляет собой однонефный храм без хоров с высокой более поздней кирпичной западной башней. Фундаменты и боковые стены храма сложены из валунов в 1400-е годы. С северной стороны к храму пристроена ризница, в центре южного фасада имеется притвор, так что получился планировочный крест. Алтарная часть была выполнена из отштукатуренного кирпича в конце XVII века. В кирхе до сих пор сохранились остатки средневековых фресок ${ }^{6}$.

Примером более позднего валунного зодчества служит храм в посёлке Яблоновка 0зёрского района Калининградской области (бывший Вильгельмсберг). Он был построен в 1725 году по приказу короля Фридриха Вильгельма I (1688-1740). Здание, сложенное из полевого камня со щебнем, представляет в плане крест, образованный выступами ризниц, расположенных с северной и южной стороны. Стены прорезаны высокими полуциркульными окнами с обрамлением из кирпича. Храм предназначался для проведения богослужений для проживавших в Вильгельмсберге лютеран и кальвинистов. В 1828-1829 годы помещение было расширено, в 1887 году в нём был установлен орган работы известного мастера Терлецкого из Кёнигсберга7. Несуществующая сейчас башня, на которой располагались два колокола, была возведена в технике фахверка, вероятно два века спустя после строительства основного объёма, её венчал флюгер с изображением орла.

Возведение храмов из полевого камня в более позднее время объясняется осознанным желанием примкнуть к древним истокам архитектуры. В конце XIX века на берегах

${ }^{6}$ Во время Второй мировой войны кирха подверглась обстрелу, о чём свидетельствовала огромная брешь в восточном фронтоне. После 1945 года использовалась под склад. В 1980-е годы нарушилась черепица, и началось активное разрушение церкви. В 2003 году фронтон и часть крыши обрушились.

Во время Второй мировой войны здание не пострадало и до 1994 года использовалось под зерносушилку. Сейчас храм заброшен. В 2010 году была передана РПЦ, но восстановительные работы не проводятся.

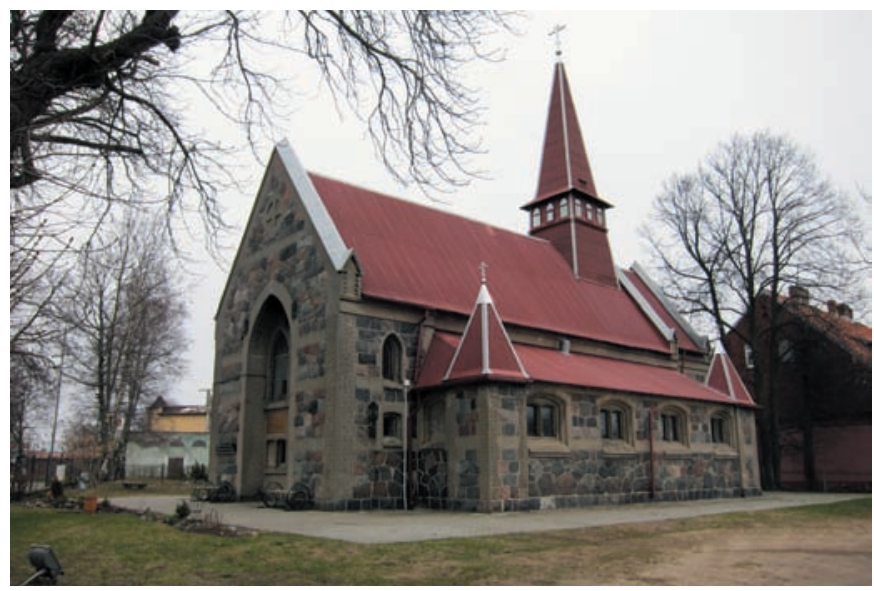

Рис. 4. Храм в посёлке Янтарный (бывш. Пальмникен). 18871892 годы. Архитектор не выявлен. Фото автора. 2011 год
Балтийского моря появляется ряд «валунных» храмов, среди которых выделяется церковь в Пальмникене (совр. пос. Янтарный Калининградской области), освящённая в 1996 году во имя иконы Казанской Божией матери. Здание из гранитных валунов с подчёркнутыми светлым раствором швами возведено в 1887-1892 годы по заказу владельца крупнейшей местной янтарной мануфактуры Морица Беккера (1830-1901) для 2000 работников его предприятия [9, s. 133-134] (рис. 4). За образец была взята капелла Святого Георгия в парке дворца Монбижу в Берлине [11, s. 24], построенная из силезского песчаника и валунных блоков по проекту архитектора Юлиуса Карла Рашдорффа. Она предназначалась для проведения англиканских богослужений (освящена в ноябре 1885 года). Мастер специально был направлен в Англию для ознакомления с местными традициями храмостроения. Капелла строилась на средства англиканской общины Берлина и под особым покровительством принцессы Виктории Английской и Ирландской (1840-1901), дочери английской королевы Виктории и супруги кронпринца Фридриха (1831-1888). Кронпринц считался одним из самых многообещающих престолонаследников Европы, но взошёл на престол, будучи уже смертельно больным, как кайзер Фридрих III и царствовал всего 99 дней (1888). Капеллу посещали во время визитов в Германию английская королева Виктория (1888), короли Эдуард II и Георг V (1913).

Требуют дальнейшего уточнения причины специфического выбора образца для строительства в Пальмникене, сделанного заказчиком храма, который исповедовал иудаизм, большую часть жизни провёл в Вене, лишь незадолго перед смертью приехал в Берлин. М. Беккер почти полвека владел монопольным правом на добычу янтаря в Восточной Пруссии. В конце XIX века, после судебного процесса, он был вынужден продать предприятие прусскому государству, оставив себе только золотодобычу в Рудном (Чехия). Я предполагаю, что строительство храма в Пальмникене по английскому образцу было вызвано меркантильно-верноподданническими соображениями промышленника. Известно, что богатый предприниматель был вхож ко двору, в 1866 году удостоен права сделать личный подарок королю Вильгельму I, а в 1885-ом - кронпринцу, будущему кайзеру Вильгельму II (1859-1941).

Почти аналогичный берлинскому, евангелический храм в честь Святого Георгия был построен в Сопоте - курортном городке вблизи Данцига (совр. Гданьск, Польша), столицы провинции Западная Пруссия. Хорошо сохранившееся здание (в настоящее время католический костёл Святого Георгия) представляет собой однонефное сооружение, поставленное на высоком склоне и украшенное стройной башней с узким готическим шпилем (1899-1901, архитектор Людвиг фон Тидеман). Как когда-то храм в Берлине, здание было возведено при содействии царствующей супружеской четы - Августы Виктории и Вильгельма II, родного внука английской королевы Виктории, - причём императрица перечислила средства на возведение храма, а император собственноручно утвердил предложенный проект. Он внёс в него некоторые изменения, настояв на 
увеличении высоты башни до сорока метров, чтобы она была видна со стороны Данцигской бухты (совр. Гданьского залива). Таким образом моряки получали дополнительный ориентир на морском берегу. 17 сентября 1901 года на торжественном открытии и освящении храма присутствовала супруга кайзера Августа Виктория. Как и в Пальмникене, в приморской церкви на берегах Балтики очевиден «английский след», связанный с обращением к древним британским прототипам каменного строительства, инициированный вкусами и родственными связями членов правящего дома Гогенцоллернов. В облике описываемых храмов сказались также общеевропейские тенденции, присущие движению национального романтизма, проявились уходящие в готическое орденское Средневековье местные традиции строительства из валунов в сочетании с кирпичом.

В Янтарном сохранилось похожее на орденскую крепость квадратное в плане сооружение невыясненного назначения, построенное во второй половине XIX века (рис. 5). Как указывал 0тто Шлихт, известный знаток культуры морского побережья Восточной Пруссии, некоторое время здание служило пивоварней, в начале XX века здесь размещалась квартира управляющего, в одном из залов проводились католические богослужения [10, s. 21-22] ${ }^{8}$.

К храмам, построенным из валунного камня, относится хорошо сохранившееся сооружение в посёлке Сосновка, Полесского района (бывш. Гросс Баум/Аугстагиррен), возведённое в 1923 году по проекту известного восточнопрусского архитектора Фридриха Ларса (1880-1964). Чем обоснован выбор строительного материала для храма в Гросс Баум, выяснить не удалось. Облик провинциальной церкви существенно отличается от неоклассического навеса над могилой Иммануила Канта, построенного годом позже - в 1924 году, тем же мастером, большим поклонником филосо$\phi a^{9}$. Как известно, после смерти прах И. Канта был погребён в «профессорском» склепе, примыкавшем к Кафедральному собору 1333 года с северной стороны. В 1809 году склеп из-за ветхости снесли, на его месте построили прогулочную галерею, которая называлась «Стоя Кантиана» (Stoa Kantiana), а затем и антикизированную стою в виде высокого портика, сохранившуюся до настоящего времени.

Необычные примеры валунного строительства на территории Восточной Пруссии представляют собой башни Бисмарка, строившиеся в память об известном «железном канцлере» 0тто фон Бисмарке (1815-1898), осуществившем план объединения Германии и способствовавшем созданию Второго рейха. В период с 1869-го по 1934 год в четырёх частях света: Европе, Африке, Америке и Австралии были построены примерно 250 таких башен. Они возводились в стилях, соответствовавших

${ }^{8}$ В настоящее время в здании разместился краеведческий музей «янтарная палата».

${ }^{9}$ Как член Общества друзей Канта в 1936 году Ф. Ларс получил почётную возможность выступить с так называемой «Боненреде» («Bohnenrede»). 0н создал по этому поводу папку литографий под названием «Город Канта, 8 изображений Кенигсберга XVIII века». архитектурным традициям местности. До наших дней в разных точках планеты, где проживали немцы - от Германии и до Чили и Камеруна, заканчивая государством Папуа Новая Гвинея, сохранились 175 башен. Монументальные сооружения, поставленные на возвышенностях, среди живописного природного окружения, служили смотровыми площадками, в день рождения канцлера до конца Второй мировой войны вокруг них разводили праздничные костры и совершали обрядовые действа.

В своих мемуарах кайзер Вильгельм II, в целом недолюбливавший 0. Бисмарка, отдавал должное влиянию этого политического деятеля на развитие Германии в конце XIX века. Он писал: «Я преклонялся перед ним и обоготворял его. И это не могло быть иначе. Надо принять во внимание, в каком поколении я вырос. Это было поколение поклонников Бисмарка. Он был создатель Германского государства, паладин моего деда [кайзера Вильгельма I. - И.Б.]. Мы все считали его величайшим государственным деятелем своего времени и гордились тем, что он немец. Бисмарк был в моём храме идолом, которому я молился». Далее монарх продолжил о собственном разочаровании: «Но... князь Бисмарк тяжёлыми ударами в своей борьбе против меня сам разбил того идола...» [11, с. 3].

В обширный список государств, имеющих памятники Бисмарку, попала и Россия, где на бывшей территории Восточной Пруссии стоят частично сохранившиеся до настоящего времени башни в Горине (бывш. Обер-Айсельн) ${ }^{10}$, Красной

${ }^{10}$ Башня в посёлке Горино Неманского района (бывший Обер-Айсельн) возвышается на холме высотой 68 м. Инициатором строительства этой башни Бисмарка был граф Георг фон Ламсдорф. Строительство башни по проекту архитектора Шаффенхауэра было начато в 1911 году, и 17 августа 1912 года башня была торжественно открыта. Постановлением Правительства Калининградской области от 23 марта 2007 года № 132 Башня Бисмарка получила статус объекта культурного наследия местного (муниципального) значения. Башня находится в аварийном состоянии, внутренняя винтовая лестница практически полностью разрушена, облицовочные камни внешних стен большей частью утрачены.

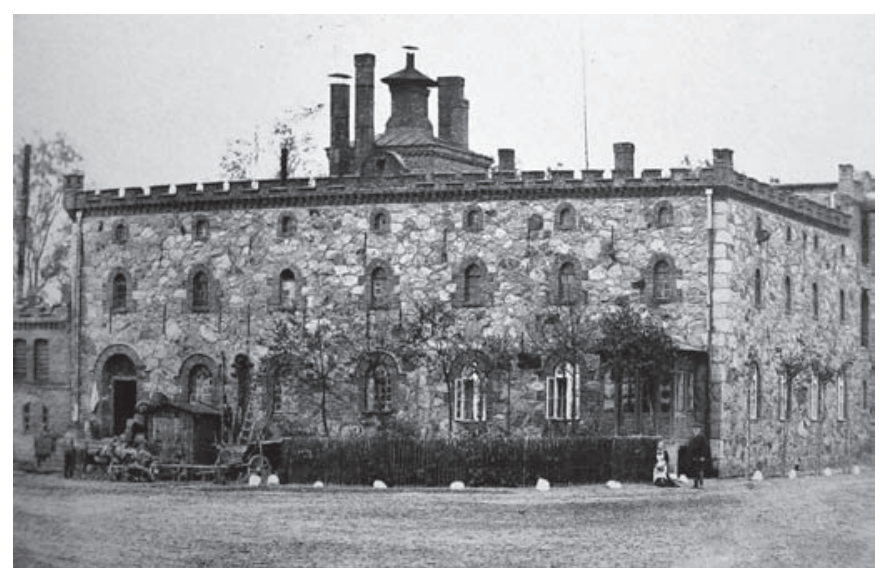

Рис. 5. «Крепость» в посёлке Янтарный (бывший Пальмникен). Вторая половина XIX векка. Архитектор не выявлен (источник: Surminski Arno. Das alte Ostpreussen. Fotografien des Königsberger Denkmalamtes von 1880 bis 1943. - Hamburg, Ellert\&Richter Verlag, 2007) 
горке (бывш. Неттинен) ${ }^{11}$. Не сохранились башни в бывш. Гальтгарбене (без имени) и в Гервишкене (в шести километрах от города Гусева, бывш. Гумбиннен).

Четыре башни Бисмарка были построены из природных неотёсанных камней на народные пожертвования по проектам разных архитекторов в 1902-1913 годах на возвышенностях от 68 м до 115 м, имели в высоту 12-22 м². Внутри располагались лестницы, ведущие на смотровые площадки. Выбор материала - крупных каменных блоков неправильной формы, диктовался не только его доступностью и дешевизной. Здесь имело место обращение к давней местной традиции крепостного зодчества. На рубеже столетий в провинции активно пропагандировался так называемый «стиль защиты Родины», основанный на поддержании патриотического движения в культуре Германии под названием «Кровь и почва» (Blut und Boden) ${ }^{13}$.
Самая известная в Восточной Пруссии башня Бисмарка высотой 22,6 м располагалась между Кумачёво (бывш. Куменен) и Переславским (бывш. Другенен), недалеко от местечка Гальтгарбен в лесу на возвышенности с отметкой $110 \mathrm{~m}^{14}$ (1906) (рис. 6). Для строительства использовались колотые гранитные валуны из каменоломен вблизи Мазура, входившего тогда в состав Западной Пруссии (совр. Польша).

Здания из валунов строились в Восточной Пруссии в межвоенное время. Среди памятников этого периода выделяется стоящее на высоком холме сооружение бывшего «партайбурга» - «партийной крепости», в Немане (бывш. Рагнит). В 1933-1945 годы в обширном сооружении с примыкающей боковой террасой размещался так называемый «замок НСДАП» ${ }^{15}$ (рис. 7 а). Внушительная каменная постройка представляет собой прямоугольное в плане здание с двускатной крышей, на углах которого выделяются невысокие массивные башни. На главном

${ }^{11}$ Башня в Красной горке (бывш. Георгенбургкелен/Неттинен) построена в 1913 году. Она имела в высоту 15 м, при небольших внутренних размерах (6×6 м). Внутри башни была устроена лестница, ведущая на смотровую площадку, сейчас разрушенная. Отсюда открывалась панорама Инстербурга (нынешний Черняховск).

${ }^{12}$ Башня в Гервишкене стояла в 6-8 км к югу от Гумбиннена (совр. Гусев) на холме высотой 115 м. 0на строилась с апреля $1902-$ го по июнь 1906 года и имела в высоту 12 м, с неё открывался замечательный вид на Гумбиннен и окрестности.

${ }^{13}$ Следует отметить, что в конце XIX - начале XX века подчёркнуто мощная открытая валунная кладка широко использовалась в нижних ярусах композиции фасадов жилых домов национально-романтического направления стиля модерн. Но это уже предмет другого исследования.

${ }^{14}$ В настоящее время на месте, где когда-то стояла башня Гальтгарбен, находится воинская часть, о судьбе остатков башни достоверно ничего не известно.

${ }^{15}$ Бытует также неподтверждённое мнение, что монументальное сооружение, сложенное из мощных, плотно прилегающих камней, было построено в 1853 году как молельный дом для меноннитов, к концу XIX века покинувших Восточную Пруссию из-за притеснений. В послевоенные годы здание использовалось как спортивный зал и клуб. В настоящее время оно заброшено и медленно разрушается.

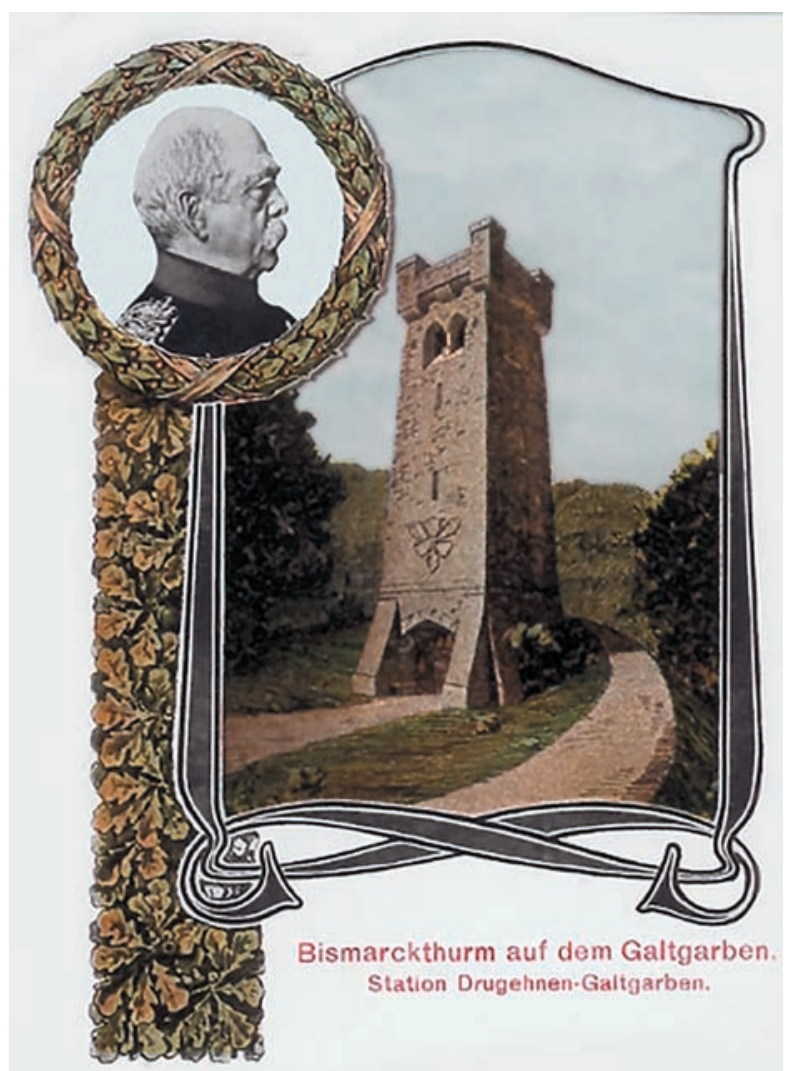

Pис. 6. Башня Бисмарка в Гальтгарбене (без совр. названия) (источник: Shot.qup.ru/http://f2.s.qip.ru/twYEFSmx.jpg. Дата обращения 23.03.2018)
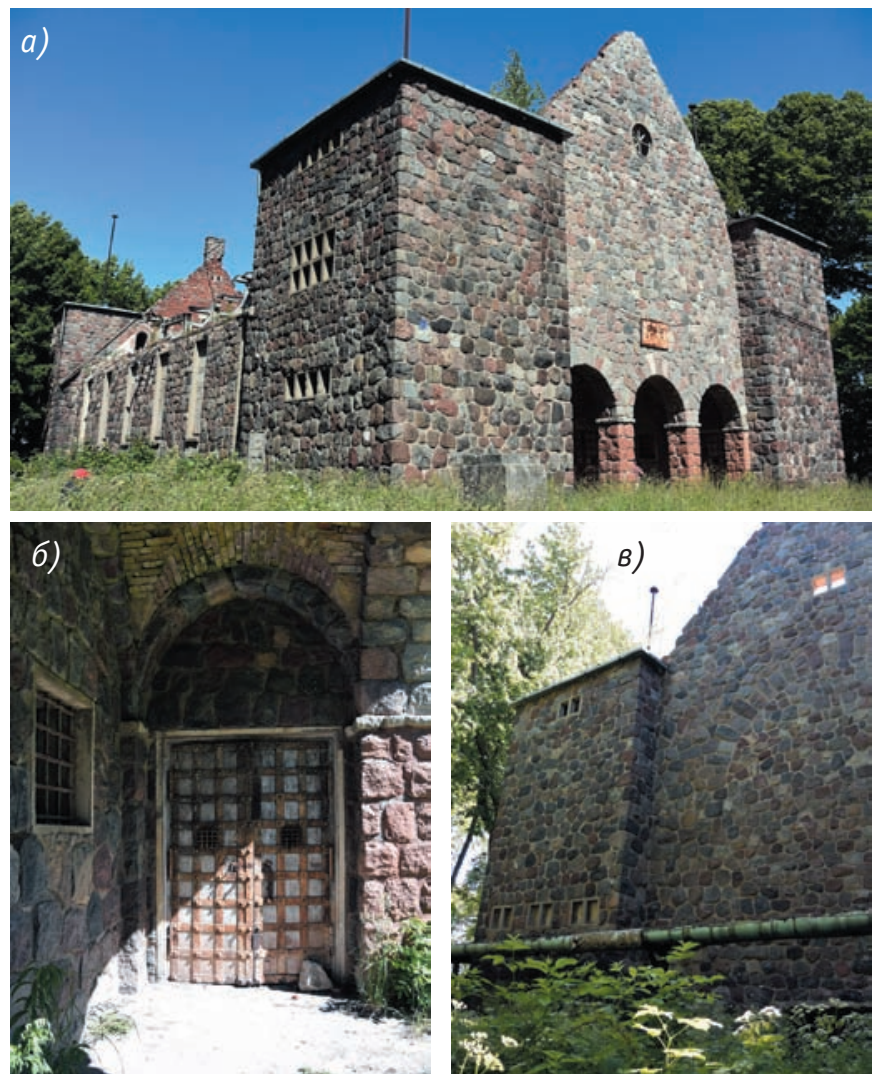

Рис. 7. Так называемый «партайбург». Город Неман (бывший Рагнит). Архитектор и точная дата строительства не выявлены (до 1933 года). Фото автора. 2017 год 
фасаде выделяются три арочных прохода одинаковой высоты, ведущие в сводчатую галерею, из которой можно попасть во внутреннее помещение. Створки, закрывающие прямоугольные проёмы, стилизованы под средневековые укреплённые двери (рис. 7 б). В центре заднего фасада отчётливо выделяется выложенный из камней круг с лучевидными выступами (рис. 7 в). До настоящего времени история появления, бытования и символика формального решения сооружения остаются не выясненными. Можно лишь предположить, что прообразом для формального решения послужили первые средневековые сооружения рыцарей Тевтонского ордена.

Использование кладки из массивных каменных глыб, колотых или сохранивших округлую природную форму, встречается в зодчестве северо-восточной части Восточной Пруссии на протяжении почти семисот лет её довоенной истории. Это крепостные, храмовые, мемориальные и хозяйственные сооружения. Выбор строительной техники зависел от многих факторов, среди которых существенную роль играла идейносимволическая нагрузка.

\section{Лuтература}

1. Рогачевский, А.Л. Кульмская грамота - памятник права Пруссии XIII в. / А.Л. Рогачевский - СПб : издательство СанктПетербургского ун-та, 2002. - 370 с.

2. Biskup, M. Dzieje Zakonu Krzyzackiego w Prusach. Gospodarstwo-Spoleczenstwo-Ideologia / Biskup M., Labuda G. - Gdansk : Wydawnictwo Morskie, 1988. - 567 p.

3. Rosenwall, $P$. Bemerkungen eines Russen über Preussen und dessen Bewohner, gesammelt einer im Jahr 1814, durch dieses Land unternommene Reise / P. Rosenwall. - Mainz, 1817. - 39 s.

4. Paravicini, W. Die Preussenreisen des europaischen Adels / Paravicini, W. // Historische Zeitschrift. Bd. 232. Heft 1. München : Oldenburg Verlag, 1981. - S. 25-38.

5. Kugler, H. Die Vorstellung der Stadt in der Literatur des deutschen Mittelalters / H. Kugler. - München, 1986. - 303 s.

6. Объекты культурного наследия Калининградской области: Иллюстрированный каталог / Сост. и гл. ред. А.М. Тарунов. - М. : Научно-информационный издательский центр, 2013. - 560 с.

7. Sonntagsausflug nach Juditten [ohne Autor] // Königbergerbürgerbrief. - 1998. - №. 50. - S. 19-21.

8. Bötticher, Adolf. Die Bau- und Kunstdenkmäler der Provinz 0stpreussen. Im Auftrage des ostpreussischen Provinzial-Landtages. Heft 1. Das Samland. - Königsberg : Kommissionsverlag von Bernh. Geichert, 1898. - 181 s.
9. Die Kirchen des Samlandes. Eine Dokumentation / Hg. Dignath Walter, Zismann Herbert. - Leer : Verlag Gerhard Rautenberg, 1987. - 231 s. - S. 133-134.

10. Schlicht 0. Das westliche Samland. Ein Heimatbuch des Kreises Fischhausen. Bd. 2. - Dresden : Verlag von Kolbe\& Schlicht, 1922. - 312 s.

11. Вильгельм II. Кайзер. Мемуары. События и люди. 1878-1918. - М. : Вече, 2017. - 336 с.

\section{References}

1. Rogachevskii A.L. Kul'mskaya gramota - pamyatnik prava Prussii XIII v. [The Kulmletter is a monument of thelaw of Prussia of the 13th century]. St. Petersburg, Publishing house of St. Petersburg University Publ., 2002, 370 p.

2. Biskup M., Labuda G. Dzieje Zakonu Krzyzackiego w Prusach. Gospodarstwo-Spoleczenstwo-Ideologia. Gdansk, Wydawnictwo Morskie Publ., 1988. 567 s.

3. Rosenwall P. Bemerkungen eines Russen über Preussen und dessen Bewohner, gesammelt einer im Jahr 1814, durch dieses Land unternommene Reise. Mainz, 1817. 39 s.

4. Paravicini W. Die Preussenreisen des europaischen Adels. Historische Zeitschrift. Bd. 232. Heft 1. München: Oldenburg Verlag, 1981. S. 25-38.

5. Kugler H. Die Vorstellung der Stadt in der Literatur des deutschen Mittelalters. München, 1986. 303 s.

6. Ob"ekty kul'turnogo naslediya Kaliningradskoi oblasti. Illyustrirovannyi katalog [Cultural Heritage Sites of the Kaliningrad Region: Illustrated Catalog]. A.M. Tarunov (ed.). Moskva, Scientific Information Publishing Center Publ., 2013, $560 \mathrm{p}$.

7. Sonntagsausflug nach Juditten. Königbergerbürgerbrief, no. 50, Sommer 1998, ss. 19-21.

8. Bötticher Adolf. Die Bau- und Kunstdenkmäler der Provinz Ostpreussen. Im Auftrage des ostpreussischen ProvinzialLandtages. Heft 1. Das Samland. Königsberg, Kommissionsverlag von Bernh, Geichert, 1898.

9. Hg. Dignath Walter, Zismann Herbert. Die Kirchen des Samlandes. Eine Dokumentation. Leer, Verlag Gerhard Rautenberg, 1987, 231 s., ss. 133-134.

10. Schlicht 0. Das westliche Samland. Ein Heimatbuch des Kreises Fischhausen. Bd. 2. Dresden, Verlag von Kolbe\& Schlicht, 1922, 312 s.

11. Vil'gel'm II. Kaizer. Memuary. Sobytiya ilyudi [Memoirs. Events and People]. 1878-1918. Moscow, Veche Publ., 2017, 336 p.

Белинцева Ирина Викторовна (Москва). Кандидат искусствоведения, доцент. Ведущий научный сотрудник Научно-исследовательского института теории и истории архитектуры и градостроительства (филиал ФГБУ «ЦНИИП Минстроя России») (111024, Москва, ул. Душинская, 9. НИИТИАГ). Эл. почта: belinceva@bk.ru.

Belinceva Irina Viktorovna (Moscow). Candidate of Art History, Associate Professor. Leading researcher at the Research Institute of Theory and History of Architecture and Urban Planning (9 Dushinskaya st, Moscow, 111024. NIITIAG), branch of the Central Institute for Research and Design of the Ministry of Construction and Housing and Communal Services of the Russian Federation (TsNIIP). Email: belinceva@bk.ru. 